\title{
F-BAR and Double SH3 Domains Protein 1
}

National Cancer Institute

\section{Source}

National Cancer Institute. F-BAR and Double SH3 Domains Protein 1. NCI Thesaurus. Code C101508.

F-BAR and double SH3 domains protein 1 ( $690 \mathrm{aa}, \sim 77 \mathrm{kDa}$ ) is encoded by the human FCHSD1 gene. This protein may be involved in signaling. 